\title{
Physical Properties of 8-Substituted 5,7-dichloro-2-styrylquinolines as Potential Light Emitting Materials
}

\author{
Grace Shiahuy Chen ${ }^{\mathrm{a}}$ ( 陳香惠), Rahul Subhash Talekar, ${ }^{\mathrm{b}}$ Ken-Tsung Wong ${ }^{\mathrm{c}}$ (汪根叢 ), \\ Liang-Chen Chi ${ }^{\mathrm{c}}$ (紀良臻) and Ji-Wang Chern ${ }^{\mathrm{b}}$ ** (陳基旺 ) \\ ${ }^{a}$ Department of Applied Chemistry, Providence University, Shalu 433, Taiwan, R.O.C. \\ ${ }^{\mathrm{b}}$ School of Pharmacy, National Taiwan University, Taipei 100, Taiwan, R.O.C. \\ ${ }^{\mathrm{c}}$ Department of Chemistry, National Taiwan University, Taipei 106, Taiwan, R.O.C.
}

\begin{abstract}
Derivatives of 5,7-dichloro-2-styrylquinoline (1), modified at position 8 of quinoline moiety with a methyl ether (4, DCSQM) or acetate (5, DCSQA), were synthesized and investigated. Both compounds exhibited high thermal stability $\left(T d>320^{\circ} \mathrm{C}\right)$. The UV-vis absorption of DCSQM and DCSQA varied only slightly in different solvents, whereas the emission spectra showed pronounced red shifts with increasing solvent polarity, suggesting the intramolecular charge transfer character of the emission state. Compounds $\mathbf{4}$ and $\mathbf{5}$ can emit lights from blue to green color in different solvents. The solvent polarity dependent electronic transitions are attributed to efficient intramolecular charge transfer (ICT) processes, in which the HOMOs and LUMOs are localized on the styrene-based ring and the quinoline-based moiety, respectively. The quinoline-based LUMO provides compelling evidence that the first reduction site occurs on the electron-deficient quinoline moiety.
\end{abstract}

Keywords: Optical materials; Crystal structure; Electronic structure; Density functional theory.

\section{INTRODUCTION}

Since the discovery of tris(8-quinolinolato)aluminum $\left(\mathrm{AlQ}_{3}\right)^{1}$ and poly $\left(p\right.$-phenylene-vinylene) $(\mathrm{PPV})^{2}$ as electroluminescent materials, a great deal of effort has been devoted to the synthesis of novel emitters. Among them, $\pi$ conjugated donor-acceptor (D- $\pi$-A) organic molecules that feature efficient intramolecular charge transfer (ICT) have attracted much attention. ${ }^{3}$ The chromophores are usually composed of a $\pi$-conjugation system such as polyenes as linkers connecting an electron donor and an electron acceptor. Chemical modification of the conjugated backbones allows efficient manipulation of physical properties that are important for determining the characteristics of light emission, namely the band gap and the electronic behavior. ${ }^{4}$

For material research, numerous styryl compounds have been investigated due to their photonic and electronic properties. ${ }^{3}$ Quinoline is an electron-deficient system with good thermal stability. ${ }^{5}$ Theoretical studies have demonstrated that molecular orbitals governing electroluminescence of $\mathrm{AlQ}_{3}$ are localized on an 8-phenoxide oxygen of quinolinolates. ${ }^{6 a}$ Recent studies revealed that several 8-hydroxyquinoline (8-HQ) derivatives with various substitu- ents had excellent electroluminescent properties and could also be used as chemosensors. ${ }^{7}$ It was reported that ether derivatives of 8-HQ enhanced the fluorescence due to the blockage of excited-state intramolecular proton transfer (ESIPT) from 8-OH to the $\mathrm{N}$ atom ${ }^{8}$ while ester derivatives of 8-HQ exhibited weak fluorescence from the radiationless $\mathrm{n} \rightarrow \pi^{*}$ transition due to the carbonyl oxygen lone pair adjacent to the fluorophore. ${ }^{9}$ The fluorescence pattern of 8-HQ was also affected by halo substituents at the 5 - and 7 -positions. ${ }^{10}$ The electron affinity of the 8-HQ would be increased by introducing chloro substituents at the 5-and 7-positons. A linkage of the electron-defficient quinoline to the electron-rich trimethoxyphenyl ring via a $\pi$-conjugated spacer would form a D- $\pi$-A system. The aim of the present work was to exploit the physical properties of this new class of fluorescent quinoline-based styryl systems.

\section{EXPERIMENTAL}

Synthesis of 5,7-dichloro-8-methoxy-2-methylquinoline (2)

Commercially available 5,7-dichloro-8-hydroxy-2-

\footnotetext{
* Corresponding author. E-mail: chern@jwc.mc.ntu.edu.tw
} 
methylquinoline $(1,2.28 \mathrm{~g}, 0.01 \mathrm{~mol})$ was added to a mixture of THF $(25 \mathrm{~mL})$, aqueous $\mathrm{NaOH}$ solution $(1.5 \mathrm{~g} \mathrm{NaOH}$ in $\left.3 \mathrm{~mL} \mathrm{H}_{2} \mathrm{O}\right)$ and TBAB $(0.15 \mathrm{~g}) . \mathrm{CH}_{3} \mathrm{I}(1.88 \mathrm{~mL}, 0.03$ mol) was added, and the resulting yellow mixture was stirred at $40{ }^{\circ} \mathrm{C}$ for $30 \mathrm{~h} .{ }^{11}$ The mixture was then extracted with ether $(3 \times 25 \mathrm{~mL})$, and the organic layers were dried over $\mathrm{MgSO}_{4}$. Removal of solvent yielded a crude product that was purified by column chromatography (hexane/ethyl acetate 4:1), giving the methyl ether $\mathbf{2}$ as a yellowish solid (83\%). $R_{f} 0.25$ (hexane/ethyl acetate $4: 1$ ); $\mathrm{Mp} 151^{\circ} \mathrm{C}$; IR (KBr) 3024, 1588, 966, $681 \mathrm{~cm}^{-1} ;{ }^{1} \mathrm{H}$ NMR $(400 \mathrm{MHz}$, $\left.\mathrm{CDCl}_{3}\right) \delta 8.34(\mathrm{~d}, J=8.6 \mathrm{~Hz}, 1 \mathrm{H}), 7.53(\mathrm{~s}, 1 \mathrm{H}), 7.36(\mathrm{~d}, J=$ $8.6 \mathrm{~Hz}, 1 \mathrm{H}), 4.13(\mathrm{~s}, 3 \mathrm{H}), 2.77(\mathrm{~s}, 3 \mathrm{H}) ;{ }^{13} \mathrm{C}$ NMR $(100$ $\left.\mathrm{MHz}, \mathrm{CDCl}_{3}\right) \delta 160.2,151.0,143.3,133.4,126.8,126.6$, 126.2, 124.6, 123.0, 62.3, 25.6; MS ESI: $242.3(\mathrm{M}+\mathrm{H})$; Anal. Calcd for $\mathrm{C}_{11} \mathrm{H}_{9} \mathrm{NCl}_{2} \mathrm{O}$ : C, 54.57; H, 3.75; N, 5.79. Found: C, 54.50; H, 3.71; N, 5.75.

\section{Synthesis of 8-acetoxy-5,7-dichloro-2-methylquinoline} (3)

Acetic anhydride ( $1 \mathrm{~mL}, 10 \mathrm{mmol})$ was added to a solution of $\mathbf{1}(2.28 \mathrm{~g}, 10 \mathrm{mmol})$ in pyridine $(50 \mathrm{~mL})$ at $0{ }^{\circ} \mathrm{C} .{ }^{12}$ After stirring for $6 \mathrm{~h}$, pyridine was removed by evaporation, and $3 \mathrm{M} \mathrm{HCl}(50 \mathrm{~mL})$ was added to the residue. The aqueous solution was extracted with $\mathrm{CHCl}_{3}$, and the organic layer was washed with water, dried over $\mathrm{MgSO}_{4}$, and evaporated under vacuum. The residue was purified by column chromatography (hexane/ethyl acetate 4:1) and recrystallized from ethyl acetate to yield $\mathbf{3}$ as a yellow solid (91\%). $R_{f} 0.20$ (hexane/ethyl acetate 4:1); Mp $105-106^{\circ} \mathrm{C}$ (lit. $\left.{ }^{13} 103.5-105^{\circ} \mathrm{C}\right)$; IR (KBr) 2945, 1770, 1618, 1120 $\mathrm{cm}^{-1} ;{ }^{1} \mathrm{H}$ NMR $\left(200 \mathrm{MHz}, \mathrm{CDCl}_{3}\right) \delta 8.26(\mathrm{~d}, J=8.6 \mathrm{~Hz}$, $1 \mathrm{H}), 7.56(\mathrm{~s}, 1 \mathrm{H}), 7.30(\mathrm{~d}, J=8.6 \mathrm{~Hz}, 1 \mathrm{H}), 2.69(\mathrm{~s}, 3 \mathrm{H})$, $2.51(\mathrm{~s}, 3 \mathrm{H}) ;{ }^{13} \mathrm{C}$ NMR $\left(100 \mathrm{MHz}, \mathrm{CDCl}_{3}\right) \delta 168.4,161.1$, $142.5,141.5,132.9,128.8,126.7,126.1,124.1,123.3$, 25.4, 20.5; MS ESI: $269.7(\mathrm{M}+\mathrm{H})$.

\section{Synthesis of 5,7-dichloro-8-methoxy-2-[2-(3,4,5-tri- methoxyphenyl)vinyl]quinoline (4)}

To a mixture of $2(0.5 \mathrm{~g}, 2.2 \mathrm{mmol})$ in acetic anhydride $(11 \mathrm{~mL})$ was added 3,4,5-trimethoxybenzaldehyde $(0.65 \mathrm{~g}, 3.3 \mathrm{mmol})$. The mixture was heated at reflux for 48 $\mathrm{h}$ under argon and then concentrated in vacuo. The oily residue was chromatographed on silica gel (hexane/ethyl acetate 4:1) to provide a solid, which was recrystallized from hexane/ethyl acetate to yield $\mathbf{4}$ as a yellowish solid (76\%). $R_{f} 0.18$ (hexane/ethyl acetate $4: 1$ ); $\mathrm{Mp} 180^{\circ} \mathrm{C}$; IR (KBr)
2943, 1581, 1509, $1131 \mathrm{~cm}^{-1} ;{ }^{1} \mathrm{H}$ NMR (400 MHz, $\left.\mathrm{CDCl}_{3}\right)$ $\delta 8.42(\mathrm{~d}, J=8.8 \mathrm{~Hz}, 1 \mathrm{H}), 7.72(\mathrm{~d}, J=8.8 \mathrm{~Hz}, 1 \mathrm{H}), 7.62(\mathrm{~d}$, $J=16.2 \mathrm{~Hz}, 1 \mathrm{H}), 7.53(\mathrm{~s}, 2 \mathrm{H}), 7.35(\mathrm{~d}, J=16.2 \mathrm{~Hz}, 1 \mathrm{H})$, $6.86(\mathrm{~s}, 1 \mathrm{H}), 4.2(\mathrm{~s}, 3 \mathrm{H}), 3.92(\mathrm{~s}, 6 \mathrm{H}), 3.88(\mathrm{~s}, 3 \mathrm{H}) ;{ }^{13} \mathrm{C}$ NMR $\left(100 \mathrm{MHz}, \mathrm{CDCl}_{3}\right) \delta 156.5,153.3,151.2,143.5$, $139.2,135.8,133.8,131.8,127.8,127.2,127.0,126.2$, 125.2, 119.9, 104.6, 62.5, 61.0, 56.3. MS ESI: $419.9(\mathrm{M}+$ H); Anal. Calcd for $\mathrm{C}_{21} \mathrm{H}_{19} \mathrm{NCl}_{2} \mathrm{O}_{4}: \mathrm{C}, 60.01 ; \mathrm{H}, 4.56$; N, 3.33. Found: C, 59.98; H, 4.65; N, 3.28.

\section{Synthesis of 8-acetoxy-5,7-dichloro-2-[2-(3,4,5-trimeth- oxyphenyl)vinyl]quinoline (5)}

To a solution of $1(0.45 \mathrm{~g}, 2.0 \mathrm{mmol})$ in acetic anhydride $(10 \mathrm{~mL})$ was added 3,4,5-trimethoxybenzaldehyde $(0.58 \mathrm{~g}, 3 \mathrm{mmol})$. The mixture was heated at reflux for $48 \mathrm{~h}$ under argon. After evaporation under vacuum, the oily residue was chromatographed on silica gel (hexane/ethyl acetate 3:2) to provide a solid, which was recrystallized from hexane/ethyl acetate to yield 5 as a yellow solid (81\%). $R_{f}$ 0.16 (hexane/ethyl acetate 4:1); Mp $178{ }^{\circ} \mathrm{C}$; IR (KBr) 2940, 1775, 1578, 1131, $961 \mathrm{~cm}^{-1}$; ${ }^{1} \mathrm{H}$ NMR $(400 \mathrm{MHz}$, $\left.\mathrm{CDCl}_{3}\right) \delta 8.38(\mathrm{~d}, J=8.8 \mathrm{~Hz}, 1 \mathrm{H}), 7.65(\mathrm{~d}, J=8.8 \mathrm{~Hz}, 1 \mathrm{H})$, $7.55(\mathrm{~s}, 1 \mathrm{H}), 7.54(\mathrm{~d}, J=16.2 \mathrm{~Hz}, 1 \mathrm{H}), 7.15(\mathrm{~d}, J=16.2 \mathrm{~Hz}$, 1H), $6.79(\mathrm{~s}, 2 \mathrm{H}), 3.9(\mathrm{~s}, 6 \mathrm{H}), 3.88(\mathrm{~s}, 3 \mathrm{H}), 2.56(\mathrm{~s}, 3 \mathrm{H}) ;{ }^{13} \mathrm{C}$ NMR $\left(100 \mathrm{MHz}, \mathrm{CDCl}_{3}\right) \delta 168.4,157.3,153.3,142.9$, $142.2,139.3,136.2,133.4,131.7,129.0,127.5,127.2$, 126.5, 124.9, 120.7, 104.7, 61.0, 56.2, 20.7; MS ESI: 447.9 $(\mathrm{M}+\mathrm{H})$; Anal. Calcd for $\mathrm{C}_{22} \mathrm{H}_{19} \mathrm{NCl}_{2} \mathrm{O}_{5}: \mathrm{C}, 58.94 ; \mathrm{H}, 4.27$; N, 3.12. Found: C, 58.81; H, 4.34; N, 3.07.

\section{X-Ray crystallography}

Single-crystal diffraction data for DCSQA were collected on a NONIUS KappaCCD diffractometer with Mo radiation $(\lambda=0.71073 \AA)$ at $295(2) \mathrm{K}$. No significant decay was observed during the data collection. Data were processed on a PC using the SHELXTL software package. The structure was solved and refined by full-matrix least squares on $F^{2}$ values. Hydrogen atoms were fixed at calculated positions and refined using a riding mode. Crystal data and experimental details are listed in Table 1.

\section{Composition analysis and optical measurement}

Ultraviolet-visible (UV-vis) spectra were measured on a Hitachi UV-160 spectrophotometer and corrected for background due to solvent absorption. Photoluminescence (PL) spectra were obtained using a Hitachi F-4500 fluorescence spectrophotometer upon excitation at the maximum 
Table 1. Crystal data of DCSQA

\begin{tabular}{|c|c|}
\hline l formula & $\mathrm{C}_{22} \mathrm{H}_{19} \mathrm{Cl}_{2} \mathrm{NO}_{5}$ \\
\hline formula weight & 448.28 \\
\hline temperature & $295(2) \mathrm{K}$ \\
\hline wavelength & $0.71073 \AA$ \\
\hline crystal system & orthorhombic \\
\hline space group & $\mathrm{P} 2{ }_{1} 2_{1} 2_{1}$ \\
\hline unit cell dimensions & $\begin{array}{l}\mathrm{a}=5.3050(2) \AA, \mathrm{b}=12.2153(5) \AA \\
\mathrm{c}=31.6620(13) \AA\end{array}$ \\
\hline volume & $2051.84(14) \AA^{3}$ \\
\hline Z & 4 \\
\hline density (calculated) & $1.451 \mathrm{mg} / \mathrm{m}^{3}$ \\
\hline absorption coefficient & $0.351 \mathrm{~mm}^{-1}$ \\
\hline $\mathrm{F}(000)$ & 928 \\
\hline crystal size & $0.2 \times 0.15 \times 0.10 \mathrm{~mm}^{3}$ \\
\hline range for data collection & 1.79 to $27.47^{\circ}$ \\
\hline limiting indices & $\begin{array}{l}-5 \leq \mathrm{h} \leq 6,-11 \leq \mathrm{k} \leq 15 \\
-40 \leq 1 \leq 41\end{array}$ \\
\hline reflections collected & 8554 \\
\hline independent reflections & $4296\left(\mathrm{R}_{\mathrm{int}}=0.0470\right)$ \\
\hline absorption correction & Semi-empirical from equivalents \\
\hline max. and min. transmission & 0.996 and 0.934 \\
\hline refinement method & full-matrix least-squares on $\mathrm{F}^{2}$ \\
\hline data/restraints/parameters & $4296 / 0 / 272$ \\
\hline goodness-of-fit on $\mathrm{F}^{2}$ & 1.074 \\
\hline final $R$ indices $[\mathrm{I}>2 \sigma(\mathrm{I})]$ & $\mathrm{R} 1=0.0581, \mathrm{wR} 2=0.1270$ \\
\hline $\mathrm{R}$ indices (all data) & $\mathrm{R} 1=0.1178, \mathrm{wR} 2=0.1623$ \\
\hline largest diff. peak and hole & 0.255 and $-0.295 \mathrm{e}^{-3}$ \\
\hline
\end{tabular}

absorption wavelength in the same solvent after saturation with argon. Measurements of quantum yields were performed using coumarin I as a reference, and degassed dichloromethane was used as solvent. Cyclic voltammetry (CV) analyses were performed in $1.0 \mathrm{mM}$ of substrate using a Princeton Applied Research potentiostat 273A. All oxidation $\mathrm{CV}$ measurements were carried out in anhydrous $\mathrm{CH}_{2} \mathrm{Cl}_{2}$ containing $0.1 \mathrm{M}$ tetrabutylammonium hexafluorophosphate $\left(n \mathrm{Bu}_{4} \mathrm{NPF}_{6}\right)$ as a supporting electrolyte, and all reduction $\mathrm{CV}$ measurements were performed in anhydrous THF containing $0.1 \mathrm{M}$ tetrabutylammonium perchlorate $\left(n \mathrm{Bu}_{4} \mathrm{NClO}_{4}\right)$ as a supporting electrolyte, purging with argon prior to conducting the experiment. A carbon electrode (oxidation) or a glassy carbon electrode (reduction) was used as a working electrode, and a platinum wire served as a counter electrode. All potentials were recorded versus $\mathrm{Ag} / \mathrm{AgCl}$ (sat'd) as a reference electrode. Ferrocenium/ferrocene redox occurs at $\mathrm{Eo}^{\prime}=+0.54 \mathrm{~V}$ vs. $\mathrm{Ag} / \mathrm{AgCl}$ (sat'd) in $\mathrm{CH}_{2} \mathrm{Cl}_{2} / n \mathrm{Bu}_{4} \mathrm{NPF}_{6}$ and at Eo' $=+0.63 \mathrm{~V}$ vs. $\mathrm{Ag} / \mathrm{AgCl}$ (sat'd) in $\mathrm{THF} / n \mathrm{Bu}_{4} \mathrm{NClO}_{4}$. Analyses of differential scanning calorimetry (DSC) were performed using a TA Instrument DSC-2920. On a low-temperature difference scan- ning calorimeter, the sample was first heated $\left(20^{\circ} \mathrm{C} / \mathrm{min}\right)$ to the melting point, quenched with liquid nitrogen, and glass transition temperature $(\mathrm{Tg})$ was recorded by heating (10 ${ }^{\circ} \mathrm{C} / \mathrm{min}$ ) the quenched sample. Thermogravimetric analysis (TGA) was used to measure the decomposition temperature $(T d)$; this procedure was similar to that for $T g$ measurement.

\section{Computational Method}

Calculations were carried out with the GAUSSIAN $98^{14}$ program installed on an SGI Origin 3800 computer. The hybrid B3LYP functional (DFT) ${ }^{15}$ was used in cooperation with the $6-31 \mathrm{G}^{*}$ basis set. All the structures were optimized by applying the Berny algorithm using redundant internal coordinates. ${ }^{16}$ Numerical vibrational frequencies were carried out for the confirmation of a stable minimum structure obtained.

\section{RESULTS AND DISCUSSION}

A straightforward synthesis of the quinoline-based styrenes is oulined in Scheme I. 5,7-Dichloro-8-hydroxyquinaldine (1) was methylated to its methyl ether $2,{ }^{11}$ which then underwent a condensation reaction with 3,4,5-trimethoxybenzaldehyde in acetic anhydride to give the desired DCSQM (4). The DCSQA (5) was obtained directly by the same condensation reaction of 1 with 3,4,5-trimethoxybenzaldehyde in acetic anhydride. The vinylic protons with $J_{\mathrm{HH}}$ values of $16 \mathrm{~Hz}$ in the ${ }^{1} \mathrm{H}-\mathrm{NMR}$ spectra indicated the vinylene bridge in an $E$ disposition. Compound 3, the 8acetoxy derivative of $\mathbf{1}$, was prepared for comparison.

The X-ray structure of DCSQA (Fig. 1) confirms the $E$ configuration of the olefinic bond. The quinoline ring and the styryl moiety are situated in ideal coplanarity with the acetoxy group twisted out of the best plane. The methoxy groups at the $3^{\prime}$ - and $5^{\prime}$-positions of the trimethoxyphenyl ring are coplanar with the best plane while the one at the $4^{\prime}$-position angles out to minimize the steric repulsion with the neighboring methoxy groups. The same geometry has been seen in other 3,4,5-trimethoxyphenyl derivatives. ${ }^{17}$ The selected bond lengths are listed in Table 2.

DCSQM and DCSQA exhibited high thermal stability with $T_{d}$ values of $321{ }^{\circ} \mathrm{C}$ and $330{ }^{\circ} \mathrm{C}$, respectively, as evaluated by TGA (Table 3 ). The glass transition temperatures $\left(T_{g}\right)$ of DCSQM and DCSQA were determined as 35.7 ${ }^{\circ} \mathrm{C}$ and $55^{\circ} \mathrm{C}$, respectively, by DSC under a nitrogen atmo- 
Scheme I Synthesis of DCSQM (4) and DCSQA (5)<smiles>COc1c(Cl)cc(Cl)c2ccc(C)nc12</smiles>

$2(83 \%)$

3,4,5-trimethoxybenzaldehyde $\left(\mathrm{CH}_{3} \mathrm{CO}\right)_{2} \mathrm{O}$, reflux, $48 \mathrm{~h}$.<smiles>COc1cc(/C=C/c2ccc3c(Cl)cc(Cl)c(OC)c3n2)cc(OC)c1OC</smiles>
$(76 \%)$

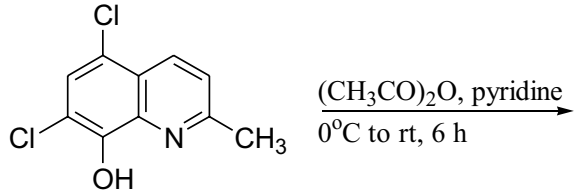
1

3,4,5-trimethoxybenzaldehyde $\left(\mathrm{CH}_{3} \mathrm{CO}\right)_{2} \mathrm{O}$, reflux, $48 \mathrm{~h}$.<smiles>COc1cc(/C=C/c2ccc3c(Cl)cc(Cl)c(OC(C)=O)c3n2)cc(OC)c1OC</smiles><smiles>CC(=O)Oc1c(Cl)cc(Cl)c2ccc(C)nc12</smiles>

$(81 \%)$

sphere. The low $T_{g}$ s might reflect the nonplanarity of the 4-methoxy group on the trimethoxyphenyl ring and the acetoxy group on the quinoline moiety, as revealed in the X-ray structure of DCSQA. The crystal lattice shows close and extensive $\pi-\pi$ stacking and the dipolar orientation is in

a

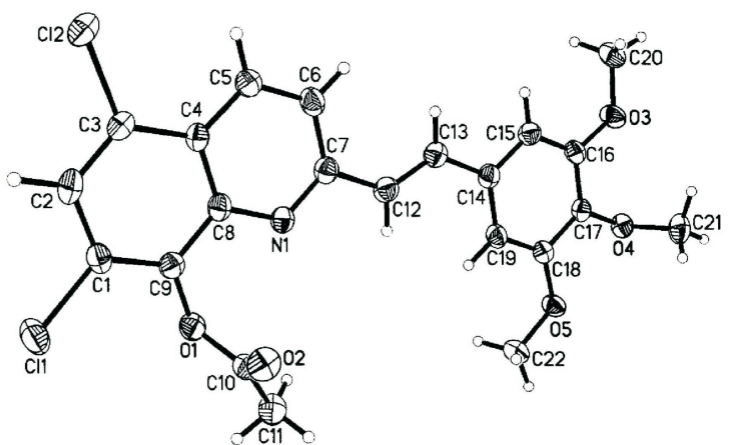

b

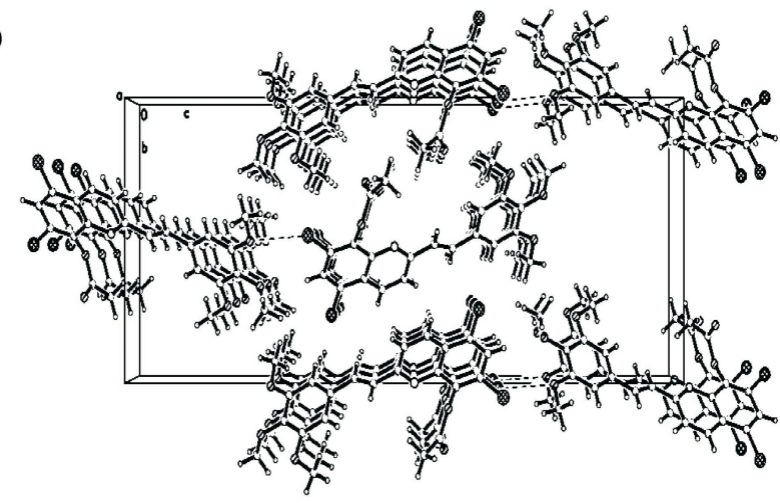

Fig. 1. Single X-ray crystal structure (a) and the molecular packing diagram (b) of DCSQA. the opposite direction to allow for the dipole-dipole interactions.

The absorption spectra of DCSQM and DCSQA in $\mathrm{CHCl}_{3}$ solution were examined to investigate the electronic

Table 2. Selected bond lengths ( $\AA$ ) for DCSQA

\begin{tabular}{lccc}
\hline atom $(1)$-atom $(2)$ & distance $(\AA)$ & atom $(1)$-atom $(2)$ & distance $(\AA)$ \\
\hline $\mathrm{Cl}(1)-\mathrm{C}(1)$ & $1.719(4)$ & $\mathrm{C}(1)-\mathrm{C}(2)$ & $1.397(6)$ \\
$\mathrm{Cl}(2)-\mathrm{C}(3)$ & $1.734(4)$ & $\mathrm{C}(1)-\mathrm{C}(9)$ & $1.366(6)$ \\
$\mathrm{O}(1)-\mathrm{C}(10)$ & $1.371(5)$ & $\mathrm{C}(2)-\mathrm{C}(3)$ & $1.367(6)$ \\
$\mathrm{O}(1)-\mathrm{C}(9)$ & $1.386(5)$ & $\mathrm{C}(3)-\mathrm{C}(4)$ & $1.422(6)$ \\
$\mathrm{O}(2)-\mathrm{C}(10)$ & $1.189(5)$ & $\mathrm{C}(4)-\mathrm{C}(5)$ & $1.402(6)$ \\
$\mathrm{O}(3)-\mathrm{C}(16)$ & $1.354(5)$ & $\mathrm{C}(4)-\mathrm{C}(8)$ & $1.413(6)$ \\
$\mathrm{O}(4)-\mathrm{C}(17)$ & $1.380(5)$ & $\mathrm{C}(5)-\mathrm{C}(6)$ & $1.364(6)$ \\
$\mathrm{O}(5)-\mathrm{C}(18)$ & $1.361(5)$ & $\mathrm{C}(6)-\mathrm{C}(7)$ & $1.417(7)$ \\
$\mathrm{N}(1)-\mathrm{C}(7)$ & $1.327(5)$ & $\mathrm{C}(7)-\mathrm{C}(12)$ & $1.466(6)$ \\
$\mathrm{N}(1)-\mathrm{C}(8)$ & $1.366(5)$ & $\mathrm{C}(13)-\mathrm{C}(14)$ & $1.475(6)$ \\
$\mathrm{C}(8)-\mathrm{C}(9)$ & $1.410(6)$ & $\mathrm{C}(12)-\mathrm{C}(13)$ & $1.316(6)$ \\
\hline
\end{tabular}

Table 3. Photophysical, thermal, and electrochemical properties of DCSQM and DCSQA

\begin{tabular}{lcc}
\hline & DCSQM & DCSQA \\
\hline$\lambda_{\max }(\mathrm{nm})^{\mathrm{a}}$ & 354 & 355 \\
$e_{\max }(\mathrm{nm})^{\mathrm{a}}$ & 465 & 474 \\
$T d\left({ }^{\circ} \mathrm{C}\right)$ & 321 & 330 \\
$T g\left({ }^{\circ} \mathrm{C}\right)$ & 36 & 55 \\
$T m\left({ }^{\circ} \mathrm{C}\right)$ & 181 & 177 \\
$\phi_{\mathrm{f}}$ & 0.44 & 0.52 \\
$\mu_{\mathrm{e}} / \mu_{\mathrm{g}}{ }^{\mathrm{b}}$ & 3.20 & 3.22 \\
\hline
\end{tabular}

${ }^{\text {a }} 5.0 \times 10^{-5} \mathrm{M}$ in $\mathrm{CHCl}_{3}$.

${ }^{\mathrm{b}}$ Calculated from the slopes of two plots in Fig. $4{ }^{22}$ 
properties. Both compounds had similar absorption spectra with maxima around $354 \mathrm{~nm}$ in $\mathrm{CHCl}_{3}$ (Fig. 2), attributed to $\pi-\pi^{*}$ transition of the conjugated system. The bathochromic shift of DCSQM and DCSQA relative to $\mathbf{2}$ and $\mathbf{3}$ demonstrated that $\pi$-electron delocalization along the vinylene bridge was enhanced between the electron-rich trimethoxyphenyl moiety and the electron-deficient quinoline ring. ${ }^{18,19}$ DCSQM and DCSQA were highly fluorescent in $\mathrm{CHCl}_{3}$ with the maximum peaks at $465 \mathrm{~nm}$ and $474 \mathrm{~nm}$, respectively. The quantum yields of DCSQM and DCSQA in $\mathrm{CH}_{2} \mathrm{Cl}_{2}$ were determined as 0.44 and 0.52 , respectively. ${ }^{20}$

The absorption of DCSQM and DCSQA varied only slightly in different solvents. However, the emission spectra showed pronounced red shifts with increasing solvent polarity for both DCSQM and DCSQA (Fig. 3). The red shift also caused a broadening of the emission band upon an increase in the solvent polarity. The solvent-dependent emission characteristics may result from the dipolar interaction with the polar solvents, suggesting the ICT character of the emission state. Changing the solvent from toluene to acetonitrile led to a 54-nm and 64-nm red shift for DCSQM

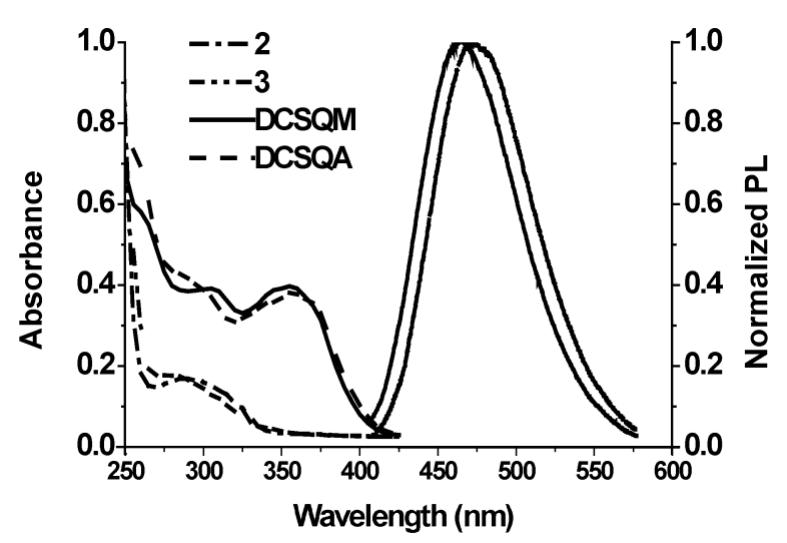

Fig. 2. Absorption and normalized photoluminescence spectra for $2 \times 10^{-5} \mathrm{M}$ of 2,3 , DCSQM, and DCSQA in $\mathrm{CHCl}_{3}$.

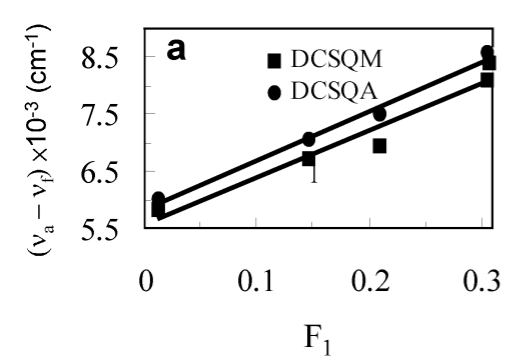

and DCSQA, respectively. This result indicates that DCSQM and DCSQA are more polar in the excited state than in the ground state. In agreement with our approach, both compounds with D- $\pi$-A structural character are thus involved in the ICT from the trimethoxyphenyl ring to the quinoline ring. As shown in Fig. 4a, the linear correlation between the Stokes shift $\left(v_{\mathrm{a}}-v_{\mathrm{f}}\right)$ and the solvent polarity parameter $\mathrm{F}_{1}\left[(\varepsilon-1) /(2 \varepsilon+1)-\left(n^{2}-1\right) /\left(2 n^{2}+1\right)\right]$ for DCSQM and DCSQA is in good agreement with the Lippert-Mataga
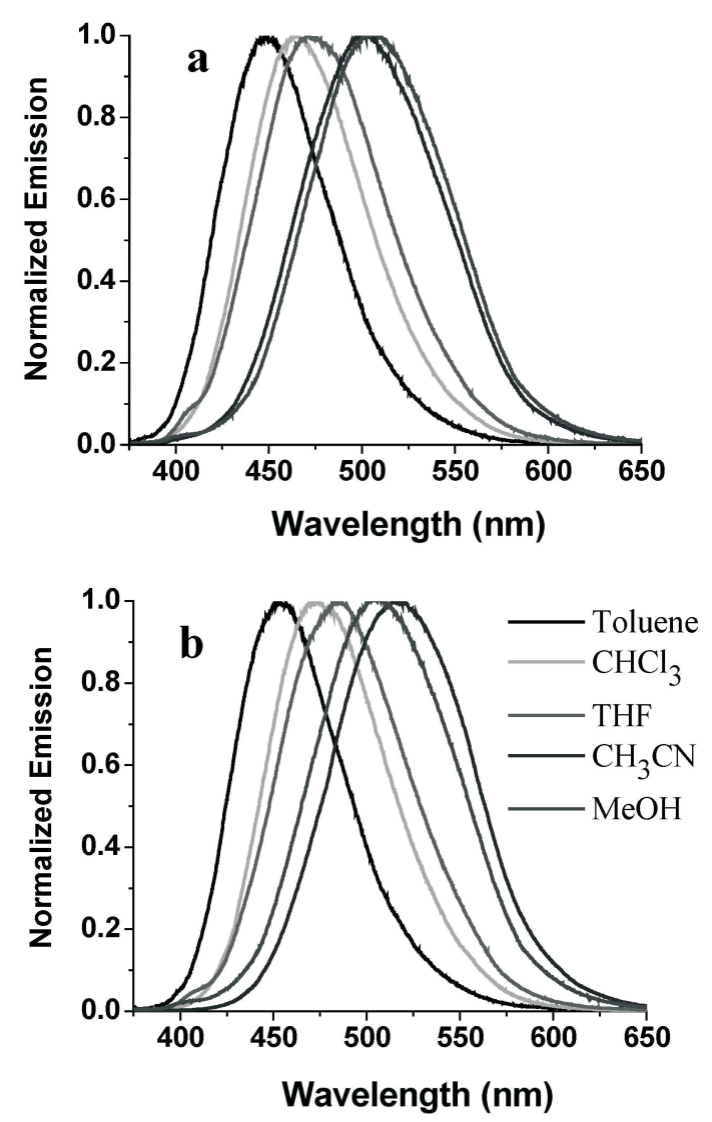

Fig. 3. Normalized photoluminescence spectra for $2 \times$ $10^{-5} \mathrm{M}$ of DCSQM (a) and DCSQA (b) in different solvents.

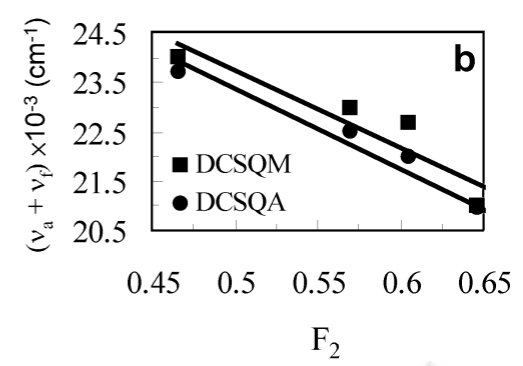

Fig. 4. (a) Plot of $\left(v_{\mathrm{a}}-v_{\mathrm{f}}\right)$ versus $\mathrm{F}_{1}=(\varepsilon-1) /(2 \varepsilon+1)-\left(n^{2}-1\right) /\left(2 n^{2}+1\right)$. (b) Plot of $\left(v_{\mathrm{a}}+v_{\mathrm{f}}\right)$ versus $\mathrm{F}_{2}=(\varepsilon-1) /(2 \varepsilon+1)+\left(n^{2}-\right.$ $1) /\left(2 n^{2}+1\right)$. 
equation. ${ }^{21}$ This result indicates that these compounds may have close structures in the ground and excited states and there are intermolecular interactions between the solvent and molecules in the excited state. The related plot of $\left(v_{a}+\right.$ $\left.v_{\mathrm{f}}\right)$ versus $\mathrm{F}_{2}\left[(\varepsilon-1) /(2 \varepsilon+1)+\left(n^{2}-1\right) /\left(2 n^{2}+1\right)\right]$ also shows a linear correlation (Fig. 4b). ${ }^{22,23}$ The ratios of the excited state dipole moment to the ground state dipole moment $\left(\mu_{\mathrm{e}} / \mu_{\mathrm{g}}\right)$ are, thus, calculated by the slopes as 3.20 and 3.22 for DCSQM and DCSQA, respectively.

Cyclic voltammetry was conducted to probe oxidation and reduction potentials and the stability of the oxidized and reduced forms. DCSQM and DCSQA had irreversible oxidation potential peaks at 1.21 and $1.24 \mathrm{~V}$ (Fig. 5 ), respectively, indicating that the resultant radical cations were not electrochemically stable. Two reduction potentials were detected for DCSQM and DCSQA; the first reduction is irrevesible, whereas the second one is quasi-reversible. Due to its electron deficiency, the quinoline moiety may provide a site for reduction in this D- $\pi$-A system. Apparently, the introduction of methoxy or acetoxy as a C8 substituent of quinoline performs a pronounced effect on the electrochemical behavior. The more electron-donating character of the $-\mathrm{OCH}_{3}$ group leads DCSQM to exhibit a lower oxidation potential and a higher reduction potential. As indicated by the potential onsets, the 8-substituted methoxy and acetoxy groups effectively perturb the LUMO energy level with a small effect on the HOMO energy level.

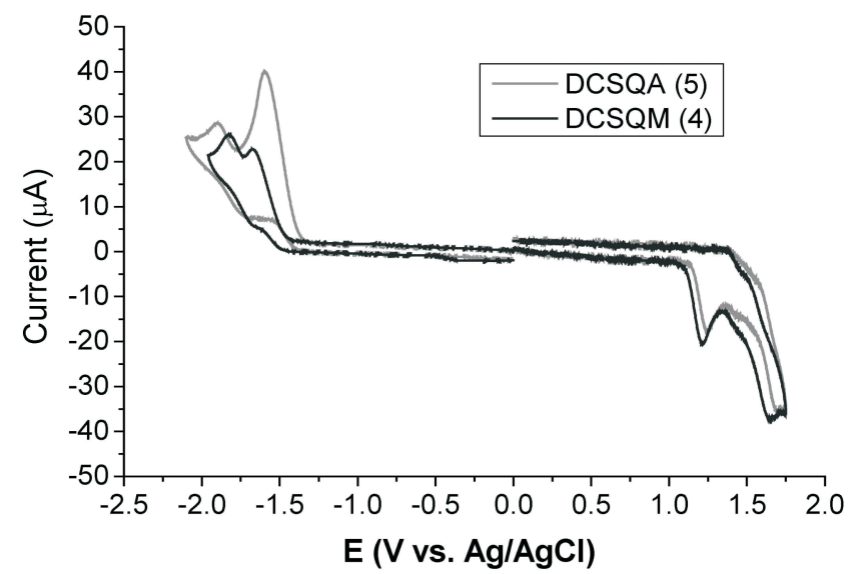

Fig. 5. Comparison of cyclic voltammograms (CV) of DCSQM (blue) and DCSQA (red). CVs were performed in THF with $0.1 \mathrm{M}$ of $n \mathrm{Bu}_{4} \mathrm{NClO}_{4}$ as a supporting electrolyte for reduction and in $\mathrm{CH}_{2} \mathrm{Cl}_{2}$ with $0.1 \mathrm{M}$ of $n \mathrm{Bu}_{4} \mathrm{PF}_{6}$ as a supporting electrolyte for oxidation. A glassy carbon electrode served as the working electrode. Scan rate $=100 \mathrm{mV} / \mathrm{s}$.
To further characterize the structural features and molecular orbitals, we carried out a theoretical approach using density functional theory at the B3LYP/6-31G* level. The most stable structure of DCSQA (5a, Fig. 6) in the ground state is in accord with that in the solid state; the two out-ofplane moieties, 4'-methoxy and 8-acetoxy groups, are on the same side of the best plane. Interestingly, the structure in which the two groups are on the opposite side is 3.75 $\mathrm{kcal} / \mathrm{mol}$ higher in energy than the most stable structure. As in the case of the crystal structure of DCSQA, planar $\pi$-conjugation is observed in both $\mathbf{4 a}$ and $\mathbf{5 a}$, with the $4^{\prime}$-methoxy group deviating by $83^{\circ}$ and $96^{\circ}$, respectively, from the plane of the trimethoxyphenyl moiety. The 8-methoxy group of $\mathbf{4 a}$ and the 8-acetoxy group of $\mathbf{5 a}$ also angle out of the best plane by $68^{\circ}$ and $74^{\circ}$, respectively, to minimize the lone pair repulsion between the $\mathrm{O}$ and $\mathrm{N}$ atoms.

The HOMOs and LUMOs of DCSQM and DCSQA involve the same localizations (Fig. 7): the HOMOs are localized on the styrene-based structure and the LUMOs are $\pi^{*}$ orbitals with contributions from nearly the entire molecule, with a larger contribution from the quinoline moiety. The quinoline-based LUMO provides compelling evidence that the first reduction site occurs on the electron-deficient quinoline moiety. Based on the orbital diagrams, the electronic transitions of DCSQM and DCSQA can be attributed
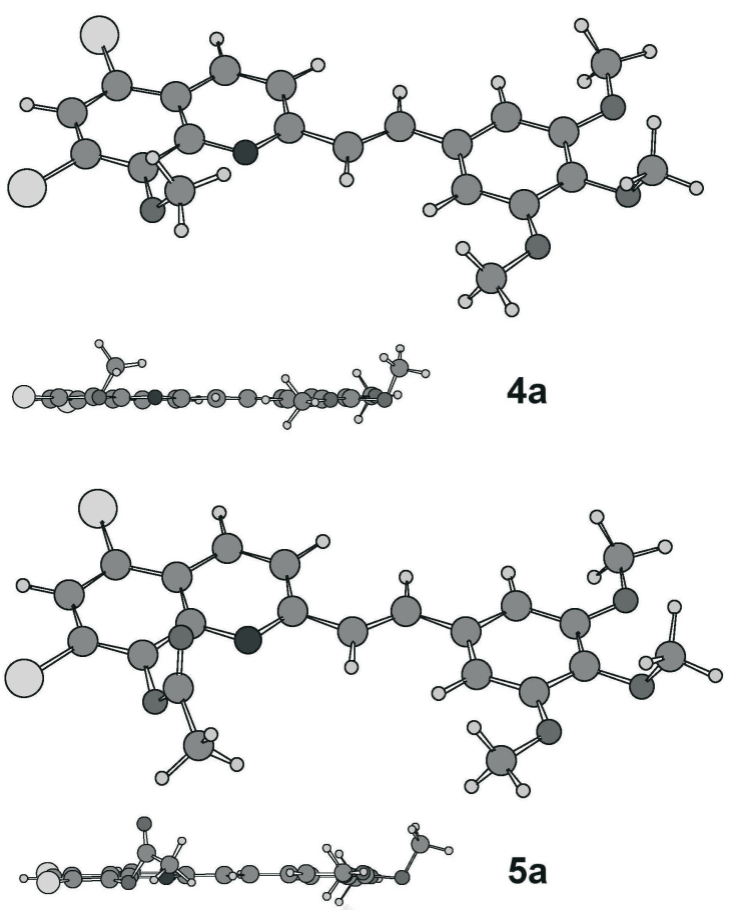

Fig. 6. The optimized structures of DCSQM (4a) and DCSQA (5a) at the B3LYP/6-31G* level. 

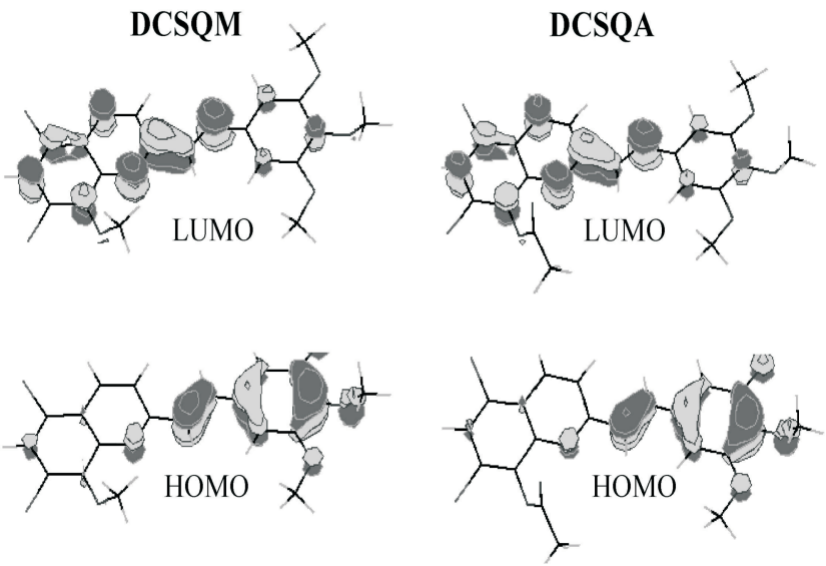

Fig. 7. The HOMO and LUMO for DCSQM and DCSQA.

to ICT from the trimethoxyphenyl ring to the quinoline moiety.

\section{CONCLUSIONS}

DCSQM and DCSQA were synthesized via a simple Knoevenagel condensation and emitted blue light in solution. X-ray structures showed that DCSQA is essentially planar, with the $4{ }^{\prime}$-methoxy and 8-acetoxy groups angled out of the plane; extensive intermolecular $\pi-\pi$ stacking interactions were also revealed. The solvent polarity dependent emissions together with the styryl-localized HOMOs and quinoline-localized LUMOs indicated that the electronic transitions could be attributed to an efficient intramolecular charge transfer from the trimethoxyphenyl ring to the quinoline moiety. Electrochemical properties revealed the importance of structural modification on the quinoline moiety upon the physical properties by introducing C8 substituents with different electronic characters. The derivatives of 5,7-dichloro-2-styrylquinoline may present a new class of potential light emitting materials.

\section{ACKNOWLEDGEMENTS}

Financial support was provided by the National Science Council, Taiwan, ROC (NSC93-2323-B-002-015 and NSC93-3112-B-002-021). We thank The National Center for High-Performance Computing, Taiwan, for computer resources.
Received March 6, 2007.

\section{REFERENCES}

1. Tang, C. W.; Vanslyke, S. A. Appl. Phys. Lett. 1987, 51, 913.

2. Burroughes, J. H.; Bradley, D. D. C.; Brown, A. R.; Marks, R. N.; Mackay, K.; Friend, R. H.; Burns, P. L.; Holmes, A. B. Nature 1990, 347, 539.

3. Meier, H. Angew. Chem. Int. Ed. 2005, 44, 2482.

4. (a) Kulkarni, A. P.; Tonzola, C. J.; Babel, A.; Jenekhe, S. A. Chem. Mater. 2004, 16, 4556. (b) Hughes, G.; Bryce, M. R. J. Mater. Chem. 2005, 15, 94.

5. Encyclopedia of Electrochemistry of the Elements; Bard, A. J.; Lund, H., Eds.; Marcel Dekker: New York, 1984; Vol. XV, pp 168-220.

6. (a) Novak, I.; Kovac, B. J. Org. Chem. 2004, 69, 5005. (b) Chen, M.-Y.; Hsu, M.-A.; Liu, C-Y.; Chow, T. Y. J. Chin. Chem. Soc. 2004, 51, 735.

7. (a) Jotterand, N.; Pearce, D. A.; Imperiali, B. J. Org. Chem. 2001, 66, 3224. (b) Shults, M. D.; Imperiali, B. J. Am. Chem. Soc. 2003, 125, 14248. (c) Pearce, D. A.; Jotterand, N.; Carrico, I. S.; Imperiali, B. J. Am. Chem. Soc. 2001, 123, 5160 .

8. Hiratani, K. J. Chem. Soc. Chem. Commun. 1987, 960.

9. Zhou, Z.; Fahrni, C. J. J. Am. Chem. Soc. 2004, 126, 8862.

10. Bratzel, M. P.; Aaron, J. J.; Winefordner, J. D.; Schulman, S. G.; Gershon, H. Anal. Chem. 1972, 44, 1240.

11. Trecourt, F.; Mallet, M.; Mongin, F.; Queguiner, G. Synthesis 1995, 1159.

12. Hiroya, K.; Suzuki, N.; Yasuhara, A.; Egawa, Y.; Kasano, A.; Sakamoto, T. J. Chem. Soc., Perkin Trans. 1 2000, 24, 4339.

13. Bourquin, J. P.; Griot, R.; Schenker, E. Arch. Pharm. Ber. Dtsch. Pharm. Ges. 1962, 295, 383.

14. Frisch, M. J.; Trucks, G. W.; Schlegel, H. B.; Scuseria, G. E.; Robb, M. A.; Cheeseman, J. R.; Zakrzewski, V. G.; Montgomery, J. A.; Stratmann, R. E.; Burant, J. C.; Dapprich, S.; Millam, J. M.; Daniels, A. D.; Kudin, K. N.; Strain, M. C.; Farkas, O.; Tomasi, J.; Barone, V.; Cossi, M.; CAmmi, R.; Mennucci, B.; Pomelli, C.; Adamo, C.; Clifford, S.; Ochterski, J.; Petersson, G. A.; Ayala, P. Y.; Culi, Q.; Morokuma, K.; Malick, D. K.; Rabuck, A. D.; Raghavachari, K.; Foresman, J. B.; Cioslowski, J.; Ortiz, J. V.; Baboul, A. G.; Stefanov, B. B.; Liu, G.; Liashenko, A.; Piskorz, P.; Komaromi, I.; Gomperts, R.; Martin, R. L.; Fox, D. J.; Keith, T.; Al-Laham, M. A.; Peng, C. Y.; Nanayakkara, A.; Challacombe, M.; Gill, P. M. W.; Johnson, B.; Chen, W.; Wong, M. W.; Andres, J. L.; Gonzalez, C.; Head-Gordon, M.; Replogle, E. S.; Pople, J. A. Gaussian 98, Revision A.11, Gaussian, Inc.: Pittsburgh, 2001.

15. (a) Becke, A. D. J. Chem. Phys. 1993, 98, 5648. (b) Lee, C. T.; Yang, W. T.; Parr, R. G. Phys. Rev. B 1998, 37, 785. 
16. Peng, C.; Ayala, P. Y.; Schlegel, H. B.; Frisch, M. J. Comput. Chem. 1996, 17, 49.

17. (a) Zhang, J.; Chen, S.-F.; Klausmeyer, K. K.; Kane, R. R. Acta Cryst. C 2003, 59, 381. (b) Wen, C.-R.; Wang, Y.-J.; Wang, H.-C.; Sheu, H.-S.; Lee, G.-H.; Lai, C. K. Chem. Mater. 2005, 17, 1646.

18. Albota, M.; Beljonne, D.; Bredas, J. L.; Ehrlich, J. E.; Fu, J.-Y.; Heikal, A. A.; Hess, S. E.; Kogej, T.; Levin, M. D.; Marder, S. R.; McCord-Maughon, D.; Perry, J. W.; Rockel, H.; Rumi, M.; Subramaniam, C.; Webb, W. W.; Wu, X. L.; Xu, C. M. Science 1998, 281, 1653.

19. Kim, O-K.; Lehn, J.-M. Chem. Phys. Lett. 1996, 255, 147.

20. Fluorescence quantum yields were obtained in $\mathrm{CH}_{2} \mathrm{Cl}_{2}$ using the expression, $\phi_{\mathrm{f}}=\left(A_{\mathrm{sam}} / A_{\mathrm{ref}}\right) \times\left(a_{\mathrm{ref}} / a_{\mathrm{sam}}\right) \times\left(n_{\mathrm{sam}} / n_{\mathrm{ref}}\right)^{2} \times \phi_{\mathrm{f}}^{1}$, where $A_{\text {sam }}$ and $A_{\text {ref }}$ are the areas under the corrected fluorescence spectrum for sample and coumarin $1, a_{\text {sam }}$ and $a_{\text {ref }}$ are the absorbances of sample and coumarin $1, n_{\mathrm{sam}}$ and $n_{\text {ref }}$ are the refractive indices for sample and reference, respectively, and $\phi_{\mathrm{f}}^{1}$ is the quantum yield of coumarin $1(0.9)$. Vijila, C.; Ramalingam, A. J. Mat. Chem. 2001, 11, 749.

21. Lakowicz, J. R. Principles of Fluorescence Spectroscopy; Plenum Press: New York, 1983; p 190.

22. Lippert-Mataga equation: $\left(v_{\mathrm{a}}-v_{\mathrm{f}}\right)=\left[2\left(\mu_{\mathrm{e}}-\mu_{\mathrm{g}}\right)^{2} / \mathrm{hca}^{3}\right] \times[(\varepsilon-$ $\left.1) /(2 \varepsilon+1)-\left(n^{2}-1\right) /\left(2 n^{2}+1\right)\right]+\mathrm{K}$ where $v_{\mathrm{a}}$ and $v_{\mathrm{f}}$ are the peak absorption and emission frequencies $\left(\mathrm{cm}^{-1}\right), \mu_{\mathrm{e}}$ and $\mu_{\mathrm{g}}$ are the dipole moment in the excited and ground state, $\mathrm{h}$ is the Planck's constant, $\mathrm{c}$ is the speed of light, a is the Onsager cavity radius, and $\mathrm{K}$ is a constant. The related equation: $\left(\mathrm{v}_{\mathrm{a}}+\right.$ $\left.v_{\mathrm{f}}\right)=-\left[2\left(\mu_{\mathrm{e}}{ }^{2}-\mu_{\mathrm{g}}{ }^{2}\right) / \mathrm{hca}^{3}\right] \times\left[(\varepsilon-1) /(2 \varepsilon+1)+\left(n^{2}-1\right) /\left(2 n^{2}+\right.\right.$ $1)]+K^{\prime}$ where $K^{\prime}$ is a constant.

23. Koti, A. S. R.; Bhattacharjee, B.; Haram, N. S.; Das, R.; Periasamy, N.; Sonawane, N. D.; Rangnekar, D. W. J. Photochem. Photobiol. Chem. 2000, 137, 115. 